\section{Research Square}

Preprints are preliminary reports that have not undergone peer review.

They should not be considered conclusive, used to inform clinical practice, or referenced by the media as validated information.

\title{
Solitary Fibrous Tumor/Hemangiopericytoma of the Cervical Spine - A Case Report
}

haggai suisa ( $\sim$ haggsy@gmail.com )

Rambam Medical Center: Rambam Health Care Campus https://orcid.org/0000-0001-8550-4416

Galia Ronen

Rambam Medical Center: Rambam Health Care Campus

Ayelet Eran

Rambam Medical Center: Rambam Health Care Campus

Gil Ephraim Sviri

Rambam Medical Center: Rambam Health Care Campus

Euvgeni Vlodavsky

Rambam Medical Center: Rambam Health Care Campus

\section{Research Article}

Keywords: cervical spine, solitary fibrous tumor, hemangiopericytoma

Posted Date: July 27th, 2021

DOI: https://doi.org/10.21203/rs.3.rs-572075/v1

License: (c) (1) This work is licensed under a Creative Commons Attribution 4.0 International License. Read Full License 


\section{Abstract}

Introduction: Due to its rarity, the clinical and radiological characteristics of spinal solitary fibrous tumors/hemangiopericytomas remain largely unknown, with only 68 cases documented worldwide between 2000 and 2017.

Case Presentation: We report a case of a 39-year-old female patient who presented to the emergency department with complaints of persisting headaches, a numbing sensation in both arms and a progressive loss of manual dexterity. Physical and neurological examinations were unremarkable. A cervical contrast-enhanced MRI revealed an intradural intramedullary space-occupying lesion at the C3 level, accompanied by extensive edema. The patient underwent a successful cervical laminoplasty under neurophysiological monitoring with en-bloc removal of the mass. She experienced total resolution of her symptoms. Biopsy revealed a grade I solitary fibrous tumor/hemangiopericytoma of the cervical spine, positive for CD34 and STAT6. Ki-67 index was 2\%.

Conclusion: This case report combines a rare tumor subtype with a unique presentation, and may further advance our understanding of this clinical entity.

\section{Introduction}

First described by Klemperer and Rabin in 1931 [1], solitary fibrous tumors/hemangiopericytomas (SFT/HPC) are an uncommon group of rarely metastasizing tumors of fibroblastic mesenchymal origin. Although commonly perceived as intrathoracic (most often involving the visceral pleura and submesothelial connective tissues), in reality some $60 \%$ of these tumors arise outside the thoracic cavity, including the central nervous system, and are now recognized to occur anywhere in the body [1]. These tumors are considered rare - less than 2 percent of all soft tissue tumors in one of the largest retrospective series [2], the most common single site being the pleura, with 900 cases reported worldwide up to 2005 [3]. 16\% of SFTs/HPCs occur in the head and neck, including the central nervous system (CNS) [4]. SFTs/HPCs of the central nervous system are rare, usually

dural-based, and account for less than 1 percent of all primary CNS neoplasms [4,5]. These tumors typically occur at younger patients compared with other SFTs/HPCs. No known environmental or genetic risk factors are currently identified for SFTs/HPCs [6]. Of note, since the discovery of a unique and recurrent gene fusion for both SFTs and tumors histologically classified as hemangiopericytomas, the use of the latter term is discouraged in clinical practice, with restructuring of solitary fibrous tumor and hemangiopericytomas as one entity $[5,6]$.

Grossly, SFTs/HPCs are usually well circumscribed and rarely invade adjacent sites. Microscopically, these tumors are relatively hypocellular and include a thick network of collagen fibers. Mitotic activity is minimal and anaplasia occurs in less than $1 \%$ of cases. In contrast, the more aggressive phenotype (previously termed 'hemangiopericytoma' by neuropathologists) is highly cellular and tends to recur locally and metastasize [5, 7]. Immunohistochemical testing includes CD34, Bcl2, CD99, vimentin, and the highly specific STAT6 staining. Molecular testing includes the NAB2-STAT6 fusion gene - which appears to be a unique feature of SFTs/HPCs $[8,9]$.

While SFTs/HPCs are uncommon in the CNS (with only 112 reported cases worldwide until 2012) [10], SFTs/HPCs arising from the spine are very rare, with only 68 cases documented worldwide between 2000 and 2017 [11]. Based on recent reports, these tumors can be divided into 4 subtypes - vertebral, paravertebral, spinal cord and mixed, of which pure spinal cord SFTs/HPCs constitute the minority of cases. Complete surgical resection is the treatment of choice in most cases, as residual tumors may recur in $10-50 \%$ of patients and worsen prognosis and overall survival $[10,12,13]$.

We hereby present a rare case of an intradural SFT of the cervical spine.

\section{Case Presentation}

A 39-year-old previously healthy female patient presented to the Rambam Healthcare Campus Emergency Department with complaints of persisting, bilateral temporal headaches for the past 7 days. The patient was of Russian descent, and her familial history was negative for hereditary diseases. The patient reported similar headaches, albeit to a lesser degree, for the past 10 years. During the last 6 months, the headaches had gotten progressively worse and were accompanied by episodes of vomiting. She was also complaining of frequent numbing and tingling sensations in both her arms for the past month, and had increasing difficulty in 
performing gentle maneuvers, such as knitting or playing the piano. The patient had denied complaints of fever, blurred vision, weight loss or urinary problems, and was not prescribed any medications for the past year. Her physical and neurological examinations were unremarkable aside from slightly decreased pinprick sensation on the lateral aspects of both her arms. Routine laboratory tests were normal. Her brain MRI was unremarkable, while her cervical scan revealed an intradural, seemingly intramedullary space-occupying lesion at the $\mathrm{C} 3$ level, measuring $1.4 \times 1.5 \times 1.6 \mathrm{~cm}$. The lesion appeared isointense on $T 1$ and hypointense on T2-weighted images, and was homogeneously enhancing following contrast material injection. A noticeable spinal cord edema was demonstrated above and below the lesion, from $\mathrm{C} 1$ through $\mathrm{C} 6$ levels. There was no clear visualization of a dural tail (Fig. 1). The patient was offered an elective surgery to relieve the ensuing mass effect and establish a tissue diagnosis. The following week, she underwent a cervical laminoplasty at C2 and C3 levels under electrophysiological monitoring. Following careful incision of the dura, a well-defined white intradural mass was detected and carefully removed en-bloc. Macroscopically, the tumor had both an intra and an extramedullary component, and was oval and viscous in consistency, with scarce vascularity. No major complications were documented throughout the procedure. On the following day, the patient was freely mobilizing. She experienced typical paraspinal muscular pains relieved with acetaminophen and reported a noticeable improvement of her neurological symptoms. Biopsy revealed a grade I solitary fibrous tumor/hemangiopericytoma of the cervical spine, positive for CD34 and STAT6 (Fig. 2-4). Ki-67 index was $2 \%$.

\section{Discussion And Conclusions}

Due to its rarity, the clinical and radiological characteristics of spinal SFTs/HPCs remain largely unknown [13]. These tumors pose an immense presurgical challenge, since the vast majority of radiologically based diagnoses are inaccurate, judging by the literature we reviewed, with presurgical MRI sensitivity rates as low as $14 \%[13,14]$. In this case, the presurgical differential diagnosis was either meningioma or hemangioblastoma, and it was difficult to decide whether the lesion was intramedullary or not. The extensive edema surrounding the lesion made the possibility of a typical meningioma less likely, while hemangioblastoma usually exhibits extensive enhancement associated with a mural nodule, unlike SFT/HPC.

As mentioned, spinal SFTs/HPCs may arise in different locations within the spinal column, and determining the spinal anatomic structure responsible for producing these tumors is often difficult [15]. Table 1 summarizes the three largest case series on spinal SFTs/HPCs to date. Of note, the second series also includes vertebral and mixed vertebral-spinal cord cases, with only $3 / 11$ cases representing 'pure' spinal cord involvement, like in our case [13]. The median age averaged from all three series was approximately 45 years, which is somewhat older than our patient. While back pain and localized neck pain were common complaints, headaches and vomiting were not listed in the series, and seem to represent a rare initial presentation of spinal SFTs/HPCs. Upper limb involvement in the form of paresthesias, radiculopathy and myelopathy, as reported in our patient, seem to be more predominant in the Mariniello et al series [10]. Anatomical location of the intraspinal lesion also varies significantly between different publications. Put together, cervical and lumbar lesions constitute the minority of spinal SFTs/HPCs (16/62 and 11/62, respectively). Similar to our case, all lesions were iso to hypointense on MRI T1-weighted imaging. T2-weighted images varied between series, with the majority being hypointense, as in our case. Gross total resection was achieved in the vast majority of patients (52/62 patients), with the posterior approach being the most prevalent. Pathological data, including mitotic activity and immunohistochemical stains were also similar $[10,12,13]$. 
Table 1

a review of the three largest case series on spinal solitary fibrous tumors/hemangiopericytomas

\begin{tabular}{|c|c|c|c|c|c|c|c|}
\hline Series & $\begin{array}{l}\text { Number of } \\
\text { cases }\end{array}$ & $\begin{array}{l}\text { Median } \\
\text { Age }\end{array}$ & $\begin{array}{l}\text { Clinical } \\
\text { presentation }\end{array}$ & $\begin{array}{l}\text { Anatomical } \\
\text { location }\end{array}$ & $\begin{array}{l}\text { Radiologic } \\
\text { Appearance }\end{array}$ & $\begin{array}{l}\text { Treatment and } \\
\text { approach }\end{array}$ & $\begin{array}{l}\text { Pathological } \\
\text { data }\end{array}$ \\
\hline $\begin{array}{l}\text { Mariniello } \\
\text { G et al } \\
(2012) \\
{[10]}\end{array}$ & $\begin{array}{l}35 \\
\text { 'intraspinal' } \\
\text { cases (2 } \\
\text { cases plus a } \\
\text { review of } 33 \\
\text { case } \\
\text { reports), no } \\
\text { bone } \\
\text { involvement } \\
\text { mentioned }\end{array}$ & $\begin{array}{l}50 \\
\text { years }\end{array}$ & $\begin{array}{l}\text { Myelopathy } \\
(57.1 \%), \\
\text { Myeloradiculopathy } \\
(20 \%), \\
\text { radiculopathy } \\
(22.9 \%)\end{array}$ & $\begin{array}{l}\text { Thoracic } \\
(54.3 \%), \\
\text { cervical } \\
(34.3 \%) \\
\text { and lumbar } \\
\text { spine } \\
(11.4 \%)\end{array}$ & $\begin{array}{l}\text { MRI - 35/35 } \\
\text { were } \\
\text { isointense on } \\
\text { T1 and } \\
\text { hypointense } \\
\text { on T2- } \\
\text { weighted } \\
\text { images. }\end{array}$ & $\begin{array}{l}\text { All cases were } \\
\text { treated } \\
\text { surgically with } \\
\text { laminotomy or } \\
\text { laminectomy. } \\
14 / 35 \text { were } \\
\text { intradural } \\
\text { extramedullary, } \\
9 / 35 \text { were } \\
\text { intramedullary } \\
\text { and } 8 / 35 \text { were } \\
\text { mixed intra } \\
\text { and } \\
\text { extramedullary } \\
\text { lesions. Gross } \\
\text { total resection } \\
\text { was achieved } \\
\text { in } 33 / 35 \\
\text { cases. In all } \\
\text { reports, the } \\
\text { tumor was of } \\
\text { hard } \\
\text { consistency, } \\
\text { scarcely } \\
\text { vascular with a } \\
\text { well-defined } \\
\text { surface. }\end{array}$ & $\begin{array}{l}\text { 35/35 were } \\
\text { positive for } \\
\text { CD34. The } \\
\text { mean Ki- } 67 \\
\text { index was } \\
\text { below } 3 \% \text {. }\end{array}$ \\
\hline $\begin{array}{l}\text { Yi X et al } \\
(2017) \\
{[13]}\end{array}$ & 11 cases & $\begin{array}{l}42 \\
\text { years }\end{array}$ & $\begin{array}{l}\text { Back pain (45\%), } \\
\text { lower extremity } \\
\text { hypoesthesia, } \\
\text { paresis and urinary } \\
\text { dysfunction (18\%) }\end{array}$ & $\begin{array}{l}\text { lumbar } \\
\text { (36.4\%), } \\
\text { thoracic } \\
(36.4 \%) \\
\text { and } \\
\text { cervical } \\
\text { spine } \\
\text { (18.2\%, } \\
\text { mostly } \\
\text { involving } \\
\text { C2-C3 } \\
\text { level) }\end{array}$ & $\begin{array}{l}\text { 8/11 were } \\
\text { well-defined. } \\
5 / 11 \text { were } \\
\text { oval. } \\
\text { CT - 11/11 } \\
\text { slightly } \\
\text { hypodense, } \\
\text { MRI - } 11 / 11 \\
\text { tumors were } \\
\text { iso to } \\
\text { hypointense } \\
\text { on T1 and } \\
\text { hyperintense } \\
\text { on T2- } \\
\text { weighted } \\
\text { images. } 9 / 11 \\
\text { showed } \\
\text { marked } \\
\text { heterogenisity } \\
\text { on contrast } \\
\text { enhanced CT } \\
\text { or MRI. The } \\
\text { mean long } \\
\text { diameter was } \\
6.24 \text { cm. }\end{array}$ & $\begin{array}{l}\text { All patients } \\
\text { were treated } \\
\text { surgically. } \\
10 / 11 \text { were } \\
\text { operated on } \\
\text { using the } \\
\text { posterior } \\
\text { approach, and } \\
\text { only } 1 \text { patient } \\
\text { was operated } \\
\text { on using the } \\
\text { anterior } \\
\text { approach. } \\
\text { Gross total } \\
\text { resection was } \\
\text { achieved in } 10 \\
\text { patients } \\
\text { (10/11, } 90.9 \% \text { ), } \\
\text { and subtotal } \\
\text { resection } \\
\text { (STR) was } \\
\text { achieved in } \\
1 \text { patient. }\end{array}$ & $\begin{array}{l}\text { Osteolytic } \\
\text { pattern was } \\
\text { found in } \\
7 / 11 \text { cases. } \\
\text { Only } 3 / 11 \\
\text { cases purely } \\
\text { involved the } \\
\text { spinal } \\
\text { canal. } \\
9 / 11 \text { were } \\
\text { positive for } \\
\text { CD34, } 7 / 11 \\
\text { had very low } \\
\text { mitotic rate } \\
\text { (less than } 4 \\
\text { mitoses/10 } \\
\text { HPF) }\end{array}$ \\
\hline
\end{tabular}




\begin{tabular}{|c|c|c|c|c|c|c|c|}
\hline Series & $\begin{array}{l}\text { Number of } \\
\text { cases }\end{array}$ & $\begin{array}{l}\text { Median } \\
\text { Age }\end{array}$ & $\begin{array}{l}\text { Clinical } \\
\text { presentation }\end{array}$ & $\begin{array}{l}\text { Anatomical } \\
\text { location }\end{array}$ & $\begin{array}{l}\text { Radiologic } \\
\text { Appearance }\end{array}$ & $\begin{array}{l}\text { Treatment and } \\
\text { approach }\end{array}$ & $\begin{array}{l}\text { Pathological } \\
\text { data }\end{array}$ \\
\hline $\begin{array}{l}\text { Wang J } \\
\text { et al } \\
\text { (2019) } \\
{[12]}\end{array}$ & $\begin{array}{l}16 \text { (pure } \\
\text { spinal cord } \\
\text { involvement, } \\
\text { no bone } \\
\text { impairment) }\end{array}$ & $\begin{array}{l}42.6 \\
\text { years }\end{array}$ & $\begin{array}{l}\text { Localized pain } \\
\text { (backache and } \\
\text { neck pain, } 94 \%), \\
\text { lower extremity } \\
\text { weakness (25\%), } \\
\text { upper limb } \\
\text { weakness (only one } \\
\text { case) }\end{array}$ & $\begin{array}{l}\text { Thoracic } \\
(56.2 \%), \\
\text { lumbar } \\
(18.8 \%) \\
\text { and } \\
\text { cervical } \\
\text { spine } \\
(25 \%)\end{array}$ & $\begin{array}{l}\text { CT - iso to } \\
\text { hypodense } \\
\text { ( } 7 / 7), \text { MRI - } \\
\text { Intradural, } \\
\text { intra or } \\
\text { extramedullary } \\
\text { lesions, iso to } \\
\text { hypointense } \\
\text { on T1 and } \\
\text { slightly } \\
\text { hyperintense } \\
\text { on T2- } \\
\text { weighted } \\
\text { images } \\
(16 / 16) .11 / 16 \\
\text { were } \\
\text { homogeneous } \\
\text { and } 5 / 16 \text { were } \\
\text { heterogeneous } \\
\text { on post } \\
\text { contrast MRI. } \\
\text { Mean long } \\
\text { diameter was } \\
2.1 \mathrm{~cm} \text {. }\end{array}$ & $\begin{array}{l}6 / 16 \text { were } \\
\text { intramedullary } \\
\text { and } 10 / 16 \\
\text { were } \\
\text { extramedullary. } \\
\text { All patients } \\
\text { were treated } \\
\text { surgically with } \\
\text { a posterior } \\
\text { laminectomy. } \\
\text { Gross total } \\
\text { resection was } \\
\text { achieved in } \\
9 / 16, \text { while the } \\
\text { rest were } \\
\text { treated with } \\
\text { subtotal } \\
\text { resection. No } \\
\text { complications } \\
\text { were observed. } \\
6 / 16 \\
\text { underwent } \\
\text { postoperative } \\
\text { radiotherapy. }\end{array}$ & $\begin{array}{l}16 / 16 \text { were } \\
\text { positive for } \\
\text { CD34 and } \\
\text { STAT6. The } \\
\text { mean Ki-67 } \\
\text { index was } \\
4.6 \% \text {. }\end{array}$ \\
\hline
\end{tabular}

Spinal SFTs/HPCs are a rare and relatively benign clinical entity, often misdiagnosed preoperatively on imaging studies. Clinical presentation varies and ranges from localized pain to neurological complaints. Most lesions will be treated operatively with extremely high success rates, as gross total resection is the usual end result.

\section{Declarations}

- Funding: No funding was received for this research

- Competing interests: The authors declare that they have no competing interests.

- Availability of data and materials: not applicable

- Authors' contributions: HS performed the literature review, summarized the case and prepared the final manuscript, GR and AE analyzed the radiological data and provided important clinical insights when drafting this manuscript. GS provided neurosurgical insights, assisted in gaining access to all relevant materials and contributed to the final manuscript. All authors read and approved the final manuscript.

- Ethics approval and consent to participate: not applicable

- Consent for publication: Written informed consent was obtained from the patient for publication of this case report and any accompanying images. A copy of the written consent is available for review by the Editor-in-Chief of this journal.

\section{References}

1. Klemperer P, Rabin CB (1931) Primary neoplasms of the pleura: a report of five cases. Arch Pathol 11:385-412

2. Gold JS, Antonescu CR, Hajdu C, Ferrone CR, et al (2002) Clinicopathologic correlates of solitary fibrous tumors. Cancer 94:1057-1068

3. Chick JF, Chauhan NR, Madan R (2013) Solitary fibrous tumors of the thorax: nomenclature, epidemiology, radiologic and pathologic findings, differential diagnoses, and management. Am J Roentgenol 200:238-248

4. Ratneswaren T, Hogg FRA, Gallagher MJ, Ashkan K (2018) Surveillance for metastatic hemangiopericytoma-solitary fibrous tumors - systematic literature review on incidence, predictors and diagnosis of extra-cranial disease. J Neurooncol 138:447-467

5. Louis DN, Ohgaki H, Wiestler OD, Cavenee WK (2016) WHO Classification of Tumors of the Central Nervous System, 4th Edition. IARC, Lyon 
6. Hall WA, Ali AN, Gullett N, Crocker I, et al (2012) Comparing central nervous system (CNS) and extra-CNS hemangiopericytomas in the Surveillance, Epidemiology, and End Results program: analysis of 655 patients and review of current literature. Cancer 18:5331-5338

7. Soyuer S, Chang EL, Selek U, McCutcheon IE, et al (2004) Intracranial meningeal hemangiopericytoma: the role of radiotherapy: report of 29 cases and review of the literature. Cancer 100:1491

8. Schweizer L, Koelsche C, Sahm F, Piro RM, et al (2013) Meningeal hemangiopericytoma and solitary fibrous tumors carry the NAB2-STAT6 fusion and can be diagnosed by nuclear expression of STAT6 protein. Acta Neuropathol 125:651-658

9. Chmielecki J, Crago AM, Rosenberg M, O'Connor R, et al (2013) Whole-exome sequencing identifies a recurrent NAB2-STAT6 fusion in solitary fibrous tumors.

Nat Genet 45:131-132

10. Mariniello G, Napoli M, Russo C, Briganti F, et al (2012) MRI Features of Spinal Solitary Fibrous Tumors: A Report of Two Cases and Literature Review. The Neuroradiology Journal 25:610-616

11. Albert GW, Gokden M (2017) Solitary fibrous tumors of the spine: a pediatric case report with a comprehensive review of the literature. J Neurosurg Pediatr 19:339-348

12. Wang J, Zhao K, Han L, Jiao L, et al (2019) Solitary fibrous tumor/hemangiopericytoma of spinal cord: a retrospective singlecenter study of 16 Cases. World Neurosurg 123:629-638

13. Yi X, Xiao D, He Y, Yin H, et al (2017) Spinal solitary fibrous tumor/hemangiopericytoma: a clinicopathologic and radiologic analysis of eleven cases. World Neurosurg 104:318-329

14. Yan PF, Yan L, Zhang Z, Salim A, et al (2016) Accuracy of conventional MRI for preoperative diagnosis of intracranial tumors: a retrospective cohort study of 762 cases. Int J Surg 36:109-117

15. Bohinski RJ, Mendel E, Aldape KD, Rhines LD (2004) Intramedullary and extramedullary solitary fibrous tumor of the cervical spine. Case report and review of the literature. J Neurosurg 100: 358-363

\section{Figures}




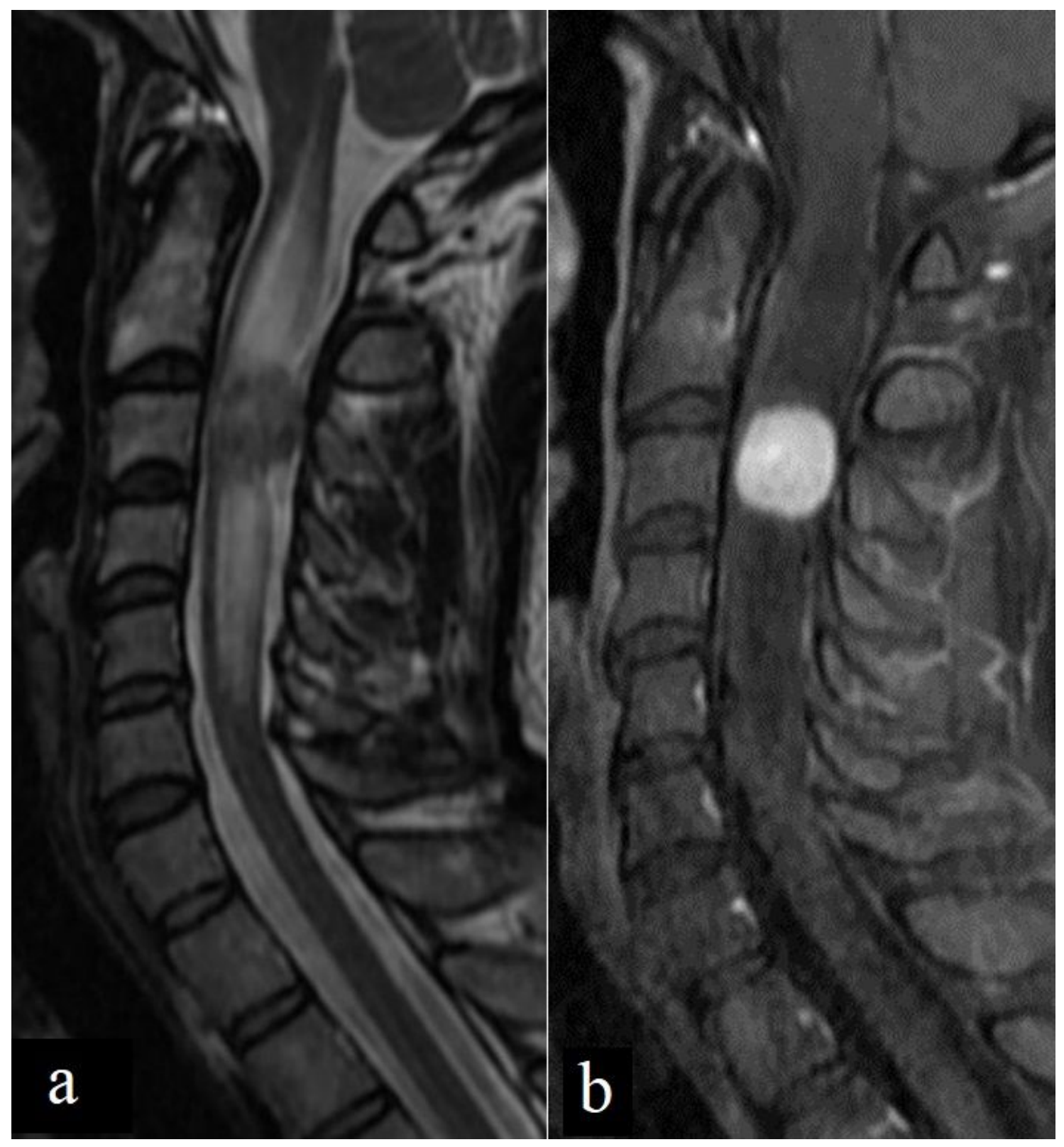

\section{Figure 1}

Sagittal T2- (1.a) and T1-weighted contrast-enhanced (1.b) MRI images through the cervical spine demonstrating a round intradural lesion at C3 level with extensive cord edema. Of note, the lesion is hypointense on T2-weighted images, with no clear evidence of a dural tail 


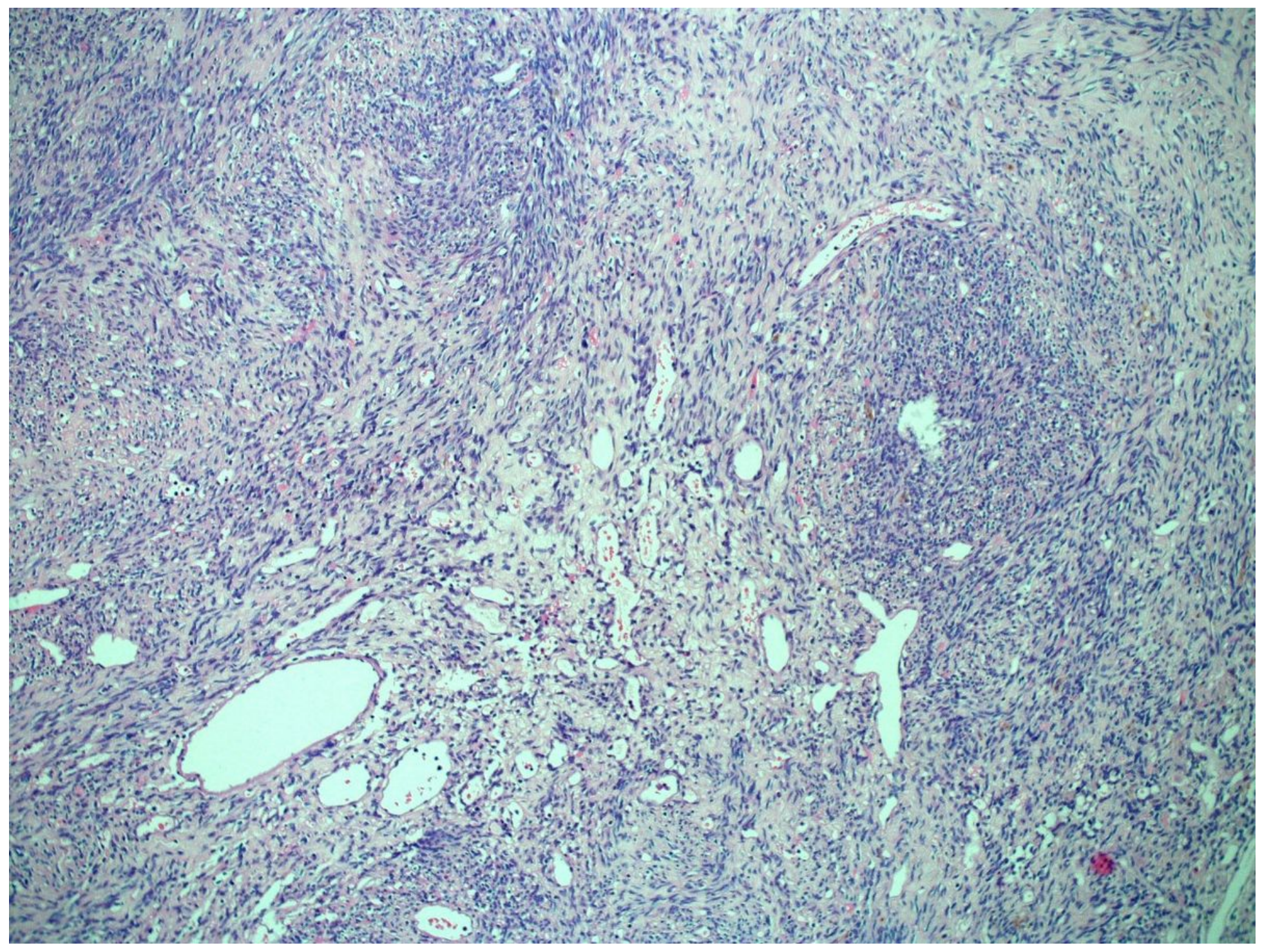

\section{Figure 2}

SFT/HPC, grade I - spindle cell tumor with a typical "patternless pattern", collagen bundles and staghorn blood vessels. Hematoxylin and eosin, $x 100$ 


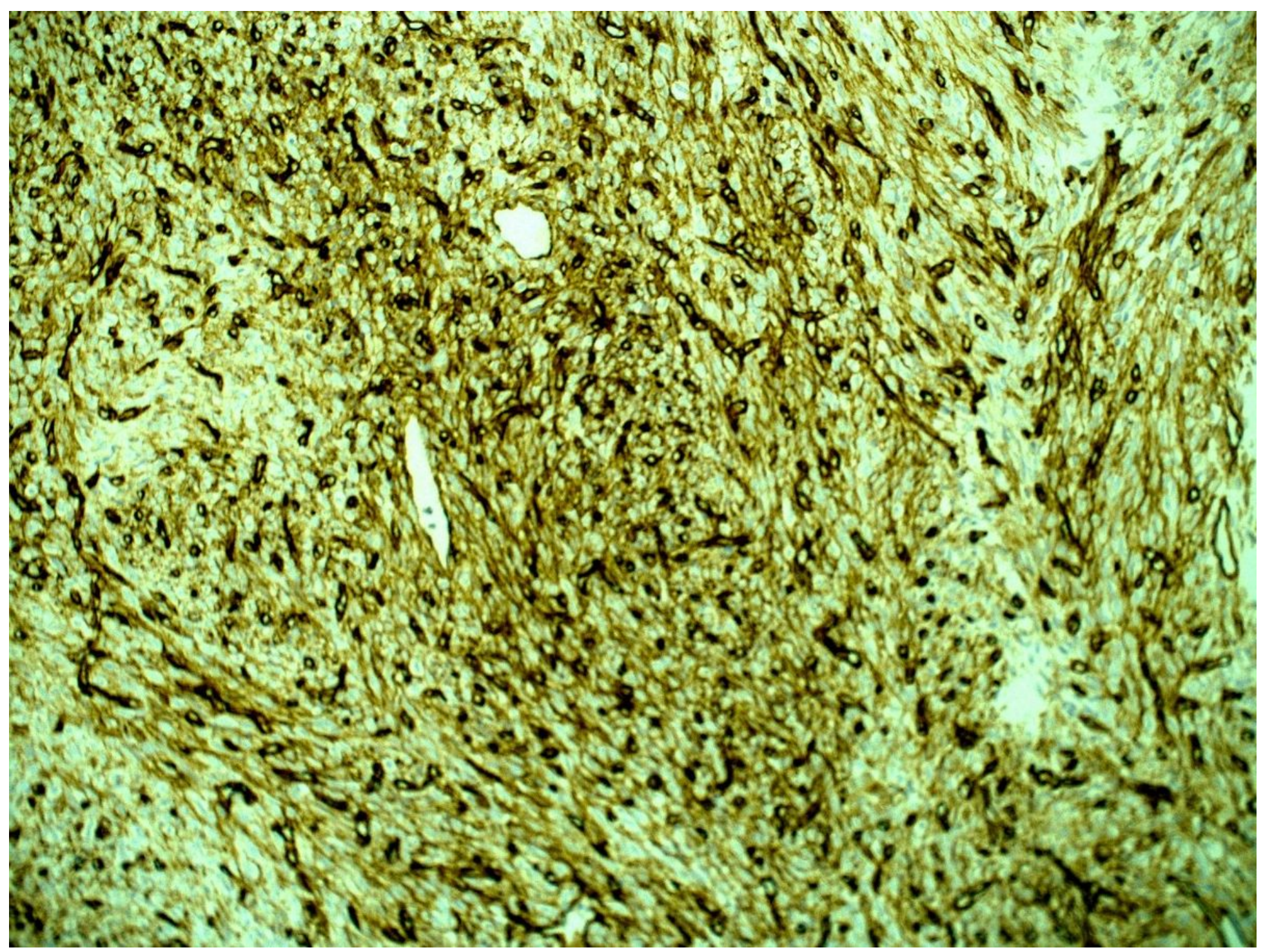

Figure 3

SFT/HPC, grade I - Positive staining for CD34, immunoperoxidase, x100 


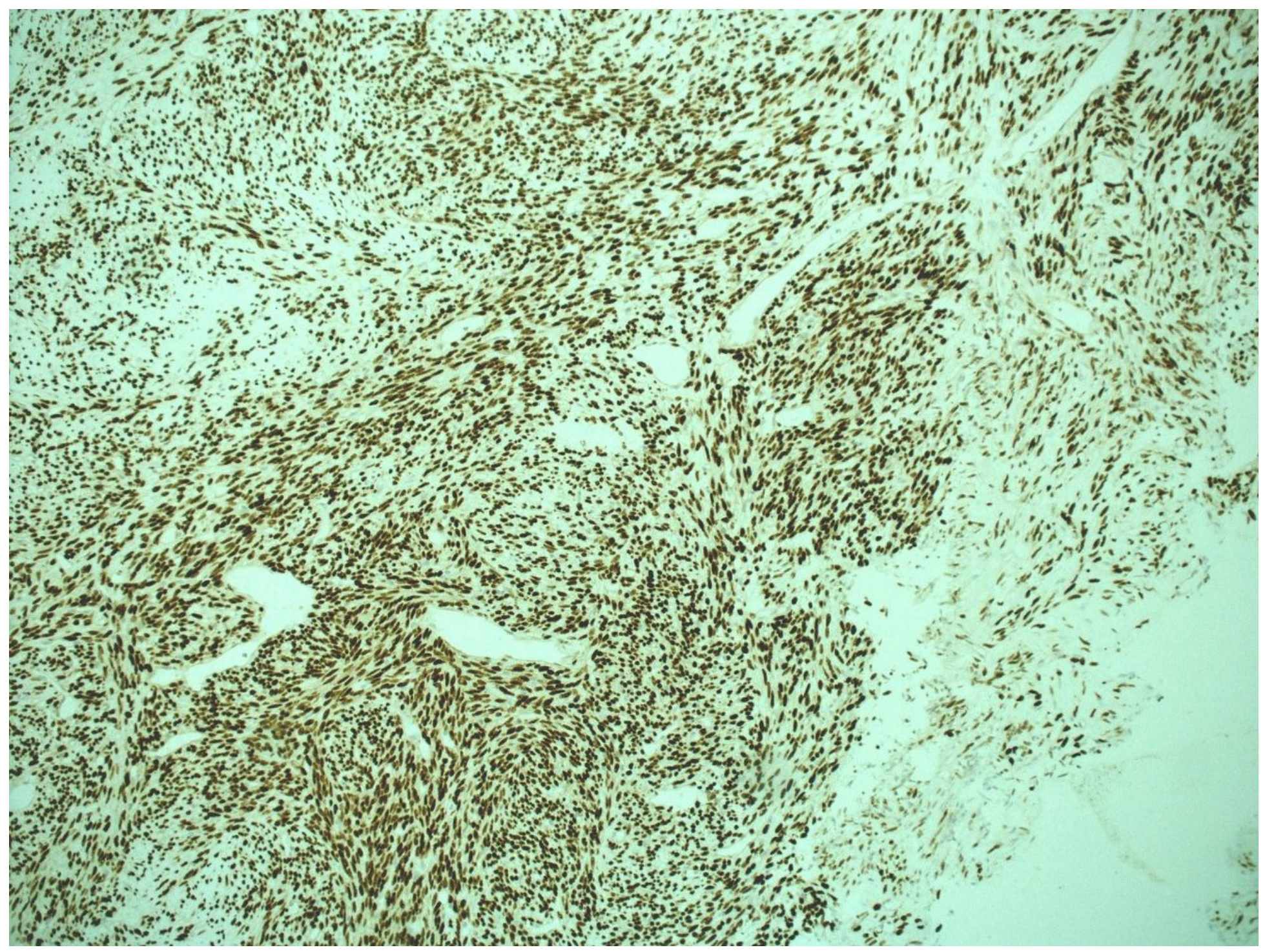

Figure 4

SFT/HPC, grade I - Diffuse positive nuclear stain for STAT6, immunoperoxidase, $\times 100$

\section{Supplementary Files}

This is a list of supplementary files associated with this preprint. Click to download.

- CARE.jpg 